ROCZNIKI TEOLOGICZNE

Tom LXVI, zeszyt 11 - 2019

DOI: http://dx.doi.org/10.18290/rt.2019.66.11-6

ANNA ZELLMA

\title{
TEACHING RELIGION AS A SPACE FOR PREVENTION OF SEXUAL ABUSE OF CHILDREN
}

\begin{abstract}
A b s t r a c t. Sexual abuse of children occurs in various social environments. Currently, this subject emerges increasingly often not only in scientific studies, but also in the public debate and in programmes of prevention and education in schools. However, there are still not enough studies on the role of religion teaching in the prevention of sexual abuse of children. Due to their educational dimension and correlation with school teaching, religion lessons play an important role in prophylactic activities. They provide the right space for taking up initiatives in the prevention of sexual abuse of children. A new curriculum for religion teaching in the primary school emphasises issues related to a safe environment and recognising threats in one's surrounding and responding properly. A religion teacher is obliged to not only look after children and ensure their safety, but also to equip them with knowledge and skills which will help them to recognise and avoid situations in which they are at risk of being abused sexually. When taking up the issues described above, this study refers both to education law and to new documents in the religious instruction curriculum. Attention was drawn to the objectives and content as well as to organisational and methodological solutions applied in preventive activities in this regard. In this context, the importance of the cooperation of a religion teacher with parents, the school and relevant services (e.g. police) was emphasised because the involvement of parents plays a very important role in preventing sexual abuse of children.
\end{abstract}

Key words: religious instruction; teacher of religion; sexual abuse; children; prevention; pedagogy.

The negative effects of the sexual abuse of children is a topical pastoral and catechetic issue. Religion teachers are obliged to participate actively in

Prof. dr hab. ANNA ZelLMA - University of Warmia and Mazury in Olsztyn, Faculty of Theology, Department of Pastoral Theology and Catechetics: address for correspondence e-mail: anna.zellma@uwm.edu.pl; ORCID: https://orcid.org/0000-0002-3612-3454.

Prof. dr hab. ANNA ZELLMA - Uniwersytet Warmińsko-Mazurski w Olsztynie, Katedra Teologii Pastoralnej i Katechetyki, adres do korespondencji - e-mail: anna.zellma@uwm.edu.pl; ORCID: https://orcid.org/0000-0002-3612-3454. 
both preventive activities and to engage in detecting situations which threaten the welfare and development of children and to respond to them. ${ }^{1}$

Analysis of contemporary catechetic literature, including studies of various aspects of teaching religion, ${ }^{2}$ reveals sporadic references to the issues mentioned above. Scholars usually write about the role of the religion teacher in preventing various forms of social maladjustment among children and youth. ${ }^{3}$ They emphasise the prophylactic and educational activities of a religion teacher. ${ }^{4}$ However, they do not write directly about the role of religion teaching in the prevention of sexual abuse of children. This issue is worth taking up, while stressing the objectives and the content as well the organisational and methodological solutions. The entire analysis will be focused on seeking an answer to the following question: should actions aimed at preventing the sexual abuse of children be taken as part of religion teaching, and if so, why and what actions should they be? This produces specific problems. They can be expressed by the following questions: what should be the goals and what subjects should be dealt with during a religion lesson concerning the prevention of sexual abuse of children? What guarantees the correctness of this type of prophylactic activities? What organisational and methodological solutions can be used by religion teachers? What problems can they face in prophylactic activities aimed at preventing the sexual abuse of children?

\footnotetext{
${ }^{1}$ See e.g. POLISH EPISCOPAl CONFEREnCE, Dyrektorium Katechetyczne Kościoła Katolickiego $w$ Polsce [Catechetic Directorium of the Catholic Church in Poland] (Kraków: Wydawnictwo WAM, 2001), no. 83 (further abbreviated as PDK); Ustawa z dnia 26 stycznia 1982 r. - „Karta Nauczyciela”, tekst jednolity, Dziennik Ustaw 2006, nr 97, poz. 674 z późn. zm. [Act of 26 January 1982 - "Teacher's Charter", consolidated text, Journal of Laws 2006, 97, item 674 as subsequently amended].

${ }^{2}$ See e.g. RYSZARD CZEKALSKI (ed.), Bibliografia katechetyczna 2001-2010 [Catechetical bibliography 2001-2010] (Warszawa: Wydawnictwo UKSW, 2012).

${ }^{3}$ See e.g. Stanisław ŁaBENDOwICZ, "Katecheza młodzieży niedostosowanej społecznie" ["Catechesis of socially maladjusted youth"], Roczniki Teologiczne 65(2018), 11: 89-112; Elżbieta TKOCZ, "Niedostosowanie społeczne młodzieży na tle wychowawczych reperkusji postmodernistycznych przemian społeczno-kulturowych" ["Social maladjustment of young people against the background of educational repercussions of post-modernistic socio-cultural transformations"], in: Wychowanie w wierze w kontekście przemian wspótczesności [Education in faith in the context of transformations of modernity], ed. R. Buchta, S. Dziekoński (Katowice: Wydawnictwo Księgarnia św. Jacka, 2011), 58-66; Anna ZELlMA, Edward WiszowaTY, "Współpraca szkoły z policją w zakresie przeciwdziałania demoralizacji nieletnich" ["Cooperation of schools with the police in preventing demoralisation of youth"], Studia Koszalińsko-Kotobrzeskie 16(2011), 127-144.

${ }^{4}$ More in: A. Zellma, "The mission of a teacher of religion in a contemporary Polish school”, Roczniki Teologiczne 65(2018), 11: 5-16.
} 
The analyses will be preceded by establishing the relevant definitions. The final part will present formal, organisational and methodological limitations, as well as those concerning the essence of the problem. The aim of study is only to provide an introduction to the debate. It does not aspire to present the issue in a comprehensive manner. A number of issues will be presented very briefly. Due to the complexity of the matter discussed, detailed analyses and an open discussion about it should be initiated in the future.

\section{DEFINITIONS}

Sexual abuse of children is a multidimensional issue, which is why literature on social science has seen an increasing number of analyses devoted to it. ${ }^{5}$ Theoretical and empirical studies, not only of the sexual abuse of children, ${ }^{6}$ but also analyses of the issue have been published, often concentrating on prevention. They usually consider the sexual abuse of children in connection with various aspects of social life as well as cultural and social transformations in Poland. ${ }^{7}$ In definitions of this phenomenon, they take into account its genesis, course and consequences. ${ }^{8}$ They also identify both the commercial sexual contacts of an adult with a child and non-commercial sexual abuse of a child ${ }^{9}$ and emphasise that sexual contacts with minors (under 15 years of age) or exposing them to pornography is a crime under the Penal Code. ${ }^{10}$

5 See e.g. Polish Scientific Bibliography, https://pbn.nauka.gov.pl/sedno-webapp/ (retrieved: 1.06.2019).

${ }^{6}$ Ibidem.

7 See e.g. Maria BeISET, Agnieszka IZDEBSKA, "Wykorzystywanie seksualne dzieci" ["Sexual abuse of children"], Dziecko Krzywdzone: teoria, badania, praktyka 2012, 2: 48-66; Jerzy BuKaŁA, Krzysztof WĄTOREK (ed.), Pedofilia jako zagrożenie XXI wieku [Paedophilia as a 21st century threat] (Kielce: Drukarnia Panzet, 2011); Kazimierz PosPISZYL, "Pedofilia: kilka poglądów na temat jej genezy" ["Paedophilia: several views on its Genesis"], Psychologia w Szkole 2004, 2: 87-93.

${ }^{8}$ Ibidem.

${ }^{9}$ Monika SAJKOWSKA, "Wykorzystywanie seksualne dzieci: ustalenia terminologiczne, skala zjawiska, oblicza problemu społecznego" ["Sexual abuse of children; terminology, scale, faces of the social issue"], Dziecko Krzywdzone: teoria, badania, praktyka 2002, 1:5-28.

${ }^{10}$ Ibidem; cf. "Act of 6 January 1997 - Penal Code", Journal of Laws Journal of Laws 1997, No. 88, item 553 as subsequently amended, Art. 197, 199, 200-202. 
This submission adopts a definition of sexual abuse developed by the World Health Organisation (WHO). It is widely accepted in social and medical sciences. According to the definition, sexual abuse of children is understood to denote "engaging a child in sexual activity which such a child cannot fully understand or grant conscious consent to, and/or to which such a child is not fully mature or to which he/she cannot express consent in a legally valid manner, and/or which is contrary to legal or social standards of a society."11 Importantly, sexual abuse of a child occurs when a child which, due to its age, is in a guardianship and dependence relation with another person (an adult, another child, a teenager), is treated by such a person as an object used to satisfy that person's (mainly sexual) needs. ${ }^{12}$

Important for proper understanding of sexual abuse of children are also statements saying that such deviant behaviour takes place both when there is physical contact between a child and a perpetrator and when there is no such contact, and the child is abused verbally and encouraged to watch pornographic content. ${ }^{13}$ This latter form of sexual abuse of children occurs increasingly often. It is facilitated by easy access to new information and communication technologies (e.g. the Internet, mobile phones, social media) in which pornographic content is presented. Perpetrators also use these technologies for grooming. ${ }^{14}$

\section{PREVENTION AND PROTECTION FROM SEXUAL ABUSE}

The perspective of religion teaching, adopted in the title of this study, may raise doubts, especially given the current debates on paedophilia in various social groups. It must be stressed clearly that - considering their educational nature and correlation with school education - religion lessons are an appropriate place for initiatives concerning the prevention of sexual abuse of chil-

\footnotetext{
${ }^{11}$ Cit. after: M. SAJKOWSKA, "Wykorzystywanie seksualne dzieci” ["Sexual abuse of children"], 7.

${ }^{12}$ Katarzyna FenIK-GABERLE, Renata KAŁUCKA, Ujawnienie przez dziecko wykorzystywania seksualnego pracownikowi oświaty. Scenariusze szkoleń dla pracowników oświaty [A child disclosing sexual abuse to a member of an educational facility personnel. Programme of training for educational personnel] (Warszawa: Ośrodek Rozwoju Edukacji, 2018), 9-10.

${ }^{13}$ Ibidem; Monika SAJKOwSKA, "Problem wykorzystywania seksualnego dzieci" ["Sexual abuse of children"], Polityka Spoteczna 31(2004), 9: 49-58.

${ }^{14}$ Cit. after: Monika SAJKOwsKa, "Wykorzystywanie seksualne dzieci” ["Sexual abuse of children”], Dziecko krzywdzone. Teoria, badania, praktyka 16(2017), 1:233-234.
} 
dren. ${ }^{15}$ Each religion teacher - under the canonical mission and the educational law - is obliged to take active part in preventive activities of the school, which is an important element of integrally perceived education. ${ }^{16}$ They are obliged to provide protection and safety for students and to support them in their holistic development. ${ }^{17}$ This, in turn, requires involvement in actions aimed at equipping children with knowledge and skills which will help them to recognise and avoid situations in which they are at risk of being abused sexually. Students should also receive information from their teacher about where they can look for help when they are abused sexually (or if such an attempt takes place), and parents should learn about strategies of swift and effective responses to such disclosures made by their child. If a religion teacher notices worrying symptoms of a child being sexually abused, they are obliged to start a conversation, to watch the child closely and to inform the school authorities. Therefore, the activity of a religion teacher in the prevention of sexual abuse of children is justified.

Lessons of religion, according to the syllabus assumptions, provide many opportunities for talking and reflecting on everything directly or indirectly related to the safety of children, harming relations with other people and situations threatening the child's good and development. ${ }^{18}$ Importantly, pro-

\footnotetext{
${ }^{15}$ See PDK, no. 83-91.

${ }^{16}$ See and cf. e.g. ibidem; "Regulation of the Minister of National Education of 14 April 1992 on conditions and methods of organising religion teaching in public schools and kindergartens", Journal of Laws 1992, no. 33, item 155 (as subsequently amended); Act of 26 January 1982 - "Teacher's Charter", item 674 as subsequently amended; Act of 14 December 2016 - "Law on Education", Journal of Laws 2017, item 59.

${ }^{17}$ Ibidem.

${ }^{18}$ See POLISH EPISCOPAl CONFERENCE, Podstawa programowa katechezy Kościoła Katolickiego w Polsce [Core curriculum of Catholic religion catechesis in Poland] (Częstochowa: Edycja Świętego Pawła, 2018), 29-93; CATHOLIC EduCATion COMMISSION OF THE Polish EPISCOPAL CONFERENCE, Klasy I-IV szkoty podstawowej. Katecheza inicjacji w sakramenty pokuty $i$ pojednania oraz Eucharystii. Zaproszeni na uczte z Jezusem [Classes I-IV of the primary school. Religious teaching in initiation of the sacrament of penance and reconciliation as well as the Eucharist. Invited to feast with Jesus], curriculum number AZ-1-01/18, in: CATHOlic EducAtion Commission of THE Polish EPISCOPAl CONFEREnCE, Program nauczania religii rzymskokatolickiej $w$ przedszkolach i szkotach [Curriculum of Catholic religion teaching at schools and kindergartens] (Częstochowa: Edycja Świętego Pawła, 2018), 39-82; Catholic Education Commission of the Polish EPISCOPal Conference, Klasy V-VIII szkoty podstawowej. Katecheza mistagogiczna, wprowadzajaca w historię zbawienia. Bóg kocha $i$ zbawia czlowieka [Classes V-VIII of the primary school. Mystagogical catechesis, introducing to the history of salvation. God loves and saves man], curriculum number AZ-2-01/18, in: CATHOlic Education Commission of the Polish EPISCOPAl Conference, Program naucza-
} 
phylaxis as part of religion teaching should start in the initial classes of the primary school because sexual abuse is suffered by children of all ages. Prophylaxis is an important element of religion teachers' involvement in creating favourable conditions for children's harmonious and integral development and for satisfying the need for safety in their educational environments (family, school, Church).

As part of the duties mentioned above, a religion teacher is obliged to pursue the objectives and curriculum of religion teaching with respect to preventing the sexual abuse of children as well as the educational and prophylactic curriculum of the school. Considering the specific nature of the Catholic religion teaching in Polish schools, such actions should be regarded as a priority, which confirm children in their belief that they are unique, beloved children of God, created in his image and likeness, ordained to holiness, which is expressed as the love of God, themselves and other people. ${ }^{19}$ Pursuing this outlined principal objective requires linking actions aimed at protecting children from contemporary threats in interpersonal interactions (direct and mediated through new information and communication technologies). Hence, the prophylactic activities of a religion teacher in the prevention of sexual abuse of children requires that they should be taught to create a safe environment for themselves and other people and to reinforce their belief in themselves. Such orientation of a religion teacher's activity is largely associated with developing social skills and attitudes, to which particular attention is drawn in new curriculum-related documents for religion teaching. ${ }^{20}$ Individual objectives and content to be pursued at a lesson, that a teacher plans and accomplishes with respect to prevention of sexual abuse of children, will stem directly from the principal objective described above.

nia religii rzymskokatolickiej $w$ przedszkolach i szkołach [Curriculum of Catholic religion teaching at schools and kindergartens] (Częstochowa: Edycja Świętego Pawła, 2018), 85-156.

${ }^{19}$ Polish EPISCOPAl Conference, Podstawa programowa katechezy Kościoła Katolickiego $w$ Polsce [Core curriculum of Catholic religion catechesis in Poland], 31-32, 57-58; CATHOLIC EDUCATION COMMISSION OF THE POLISH EPISCOPAL CONFERENCE, Klasy I-IV szkoty podstawowej. Katecheza inicjacji w sakramenty pokuty i pojednania oraz Eucharystii... [Classes I-IV of the primary school. Religious teaching in initiation of the sacrament of penance and reconciliation as well as Eucharist...], 42-45, 71-72; CATHOLIC EDUCATION COMMISSION OF THE POLISH EPISCOPAL CONFERENCE, Klasy V-VIII szkoty podstawowej. Katecheza mistagogiczna, wprowadzajaca $w$ historie zbawienia. Bóg kocha i zbawia człowieka... [Classes V-VIII of the primary school. Mystagogical catechesis, introducing to the history of salvation. God loves and saves man...], 85-86, 91, 118-119, 137-138.

${ }^{20}$ Ibidem. 
Attention should be drawn to the richness of the Catholic Church's teaching on the dignity of each person, ordaining them to holiness, their right to establish and maintain bonds based on mutual respect, truthfulness, trust, care, selfless and responsible love. ${ }^{21}$ At the same time, the issues associated with protecting oneself in interpersonal contacts are noteworthy. This, in turn, requires supporting students in acquiring the skill of responding in a threatening situation or seeking help (especially in a threatening situation) from adults. It is worth reminding children that everyone is created in God's image and likeness, they are God's children, they live and move within the space of God's grace which embraces the whole person - their body, senses, heart, soul and sexuality.

The curriculum documents for religion teaching, approved by the Polish Episcopal Conference and the Catholic Education Commission of the Polish Episcopal Conference: catechesis core curriculum and religion syllabus for kindergartens and schools, draw attention to the following issues: dignity of God's child, love and kindness of God, divine filiation, ordination to holiness, covenant with God, Credo, love and responsibility, theology of the body, modesty, virtues, safety on the Internet, responsibility for the community of the Church and its members, safe interpersonal bonds, influence of the media on personal, social and religious development, the media and observing the Ten Commandments, respecting oneself and others, truthfulness, honesty, God and human feelings, Divine Providence, communion of saints, human trafficking, harassment on the Internet. ${ }^{22}$ In the context of these issues, one can directly or indirectly - refer to the issue of healthy or unhealthy interpersonal relations, (physical and mental) boundaries in interpersonal contacts, various forms of minors neglect and abuse and the levels of closeness and violation of boundaries. However, it is not the point that threats should be emphasised and children should be made oversensitive to dangerous interpersonal relationships. This is because such actions could raise a sense of mistrust and excessive suspiciousness, even anxiety, in children which would not help them to build true bonds between children and adults. Referring to development and education-related issues, such as addiction to new information and communication technologies, helps to provide children with knowledge on threats present on the Internet and on how to avoid them. The issue of

\footnotetext{
${ }^{21}$ Ibidem.

${ }^{22}$ Cf. Ibidem.
} 
sexual abuse is linked closely with such types of violence as cyberbullying and peer violence.

The scope of these issues and the way they are conveyed should be adopted to the characteristics of the target group, i.e. the age and intellectual capacity. Therefore, of great importance are the organisational and methodological solutions employed by the teacher.

\section{ORGANISATIONAL AND METHODOLOGICAL SOLUTIONS}

A lesson of religion is doubtless a privileged place with respect to prevention of situations threatening to a child's welfare and development and responding to situations associated with sexual abuse. Like any other teacher, a teacher of religion is obliged to ensure that the children's environment is safe and to monitor changes in the children's behaviour in order to report to the school authorities all situations in which the good of a child is threatened. ${ }^{23}$ When taking up prevention issues, he/she should cooperate with the school staff, especially with the school authorities, with the school pedagogue and psychologist. Joint actions aimed at fostering the child's development and protecting them from situations threatening to their good should be regarded as significant - one of fundamental importance. Together with other teachers, a religion teacher plays a significant role not only in identifying issues related to protecting children and to initiating interventions, but also in following the prophylactic and educational syllabus.

All activities aimed at the good of a child are based on the following principles: faithfulness to God and to man, subjectivity, dialogue, visuality, gradual difficulty and multi-faceted activisation. ${ }^{24}$ Teaching religion cannot omit the relationship between prayer and the issues being dealt with and tutoring education. ${ }^{25}$ These principles imply the need to apply specific methodological propositions, and the priority should be placed on the planning of every part of a religion lesson, especially presenting the link between the Church's teaching and developing attitudes. There are also indispensable forms of students work organisation as well as didactic methods and materials

\footnotetext{
${ }^{23}$ See e.g. Act of 26 January 1982 - "Teacher's Charter", item 674 as subsequently amended; Act of 14 December 2016 - Law on Education, item 59.

${ }^{24}$ See e.g. Stanisław ŁABENDOWICZ, Dydaktyka katechezy [Didactics of catechesis] (Radom: Spatium, 2019), 79-117, 139-161.

${ }^{25}$ Ibidem.
} 
used to stimulate children's activity during a religion lesson. A religion teacher should use various methodological solutions and teaching aids which are proposed in new curriculum documents for religion teaching. ${ }^{26}$ These can include heuristic discussions and role-playing combined with controlled conversation as well as an audio-video presentation and showing an educational movie combined with a conversation and/or explanation. It will not only make it possible to accomplish the planned objectives regarding prevention of sexual abuse of children, but it will also make religion lessons more attractive.

A school retreat - instead of traditional meetings - can involve workshops devoted to such issues as: the privacy of one's body, creating a network of kind adults, rules of contacts with strangers, harming relations with others and methods of avoiding them. ${ }^{27}$ Behavioural skill training is also noteworthy. It serves developing specific skills and practicing specific behaviours, which could help children to avoid potentially dangerous situations, e.g. refusing to go with a stranger, refusing to provide one's personal details in a chat, informing adults about a dangerous situation. This, in turn, requires engaging specialists, especially psychologists, police officers and members of NGOs. ${ }^{28}$ Only properly qualified specialists will be able to have a meeting properly and to teach children to build relations and networks of good, trustworthy people.

Undoubtedly, on the organisational side, the cooperation of a religion teacher with parents is noteworthy. Considering the fundamental and considerable influence of the family and its role in holistic development of the child, a teacher should initiate dialogue with parents and support them in identifying issues and preventing situations which may endanger the good and

\footnotetext{
${ }^{26}$ POLISH EPISCOPAl CONFEREnCE, Podstawa programowa katechezy Kościoła Katolickiego $w$ Polsce [Core curriculum of Catholic religion catechesis in Poland], 43-46; CATHOLIC EDUCATION COMMISSION OF THE POLISH EPISCOPAL CONFERENCE, Klasy I-IV szkoty podstawowej. Katecheza inicjacji $w$ sakramenty pokuty i pojednania oraz Eucharystii... [Classes I-IV of the primary school. Religious teaching in initiation of the sacrament of penance and reconciliation as well as Eucharist...], 49-50, 59-60, 68-69, 77-78.

${ }^{27}$ More in: Anna ZELlma, Wojsław CZUPRYŃSKI, Hubert TRYK, Rekolekcje szkolne jako forma ewangelizacji dzieci, mtodzieży i dorostych [School retreat as a form of evangelisation of children, youth and adults] (Olsztyn: Wydawnictwo UWM w Olsztynie, 2018).

28 Those interested in the issues are referred to: Anna ZELlma, Edward Wiszowaty, O Policje bliższa ludziom. Inspiracje pedagogiczne $w$ stużbie funkcjonariuszy [Let the police be closer to the people. Pedagogical inspirations in the police service] (Szczytno: Publishing Office WSPoL, 2017).
} 
development of children. Workshops organised for parents and information leaflets on how to prevent sexual abuse of children, or where to seek help if the fact of such sexual abuse is revealed, can be helpful, as well as simple, coherent, frequent conversations on relations with other people, prevention and protection, initiated with children both within the family and as part of school activities (including in religion lessons) are very important. However, a child does not always receive adequate support and help from their parents. If this is the case, a religion teacher is obliged to respond properly and to cooperate with the school authorities and the relevant services (e.g. police) in order to ensure a safe environment and to prevent situations which endanger the child's good. The effectiveness of each of these preventive measures is guaranteed if the fundamental catechetic principle, i.e. faithfulness to God and man, is observed. Only such an approach to the prevention of sexual abuse of children creates a chance of avoiding threats.

\section{FINAL NOTES}

Undoubtedly, teaching religion at school provides one of many spaces in which actions must be taken to prevent sexual abuse of children. It stems from the fundamental principles of religion teaching. However, it requires that the principles of faithfulness to God and to man should be respected. In practice, a religion teacher can face numerous problems, mainly formal and organisational, which must be solved mainly at the school and diocese level (e.g. by the head of a catechetic department).

Considering the sensitive nature of the issues being dealt with, special pedagogic competences are required. This, in turn, requires preparing religion teachers adequately to conduct preventive activities in regard to the sexual abuse of children. At the same time, a new challenge appears regarding the permanent formation of religion teachers, who should be prepared to conduct prophylactic meetings.

Undoubtedly, such prophylactic activities regarding the sexual abuse of children (even if occasional in nature and only devoted to topics chosen by the religion teacher) would require the consent of the children's parents or legal guardians, because they have a right to know what their children are being taught in religion lessons. Parents should also be encouraged to cooperate. Therefore, it is an open issue how to inform parents about the curriculum of religion teaching and then to engage them in specific preventive actions - among other things - in an educational dialogue with children, com- 
munication between the catechist, the parent and the child. It is also associated with the need to seek new ways of encouraging parents to participate in actions aimed at preventing the sexual abuse of children.

Furthermore, it is worth considering what permanent formation of religion teachers should be involved regarding prevention and how to prepare a new series of handbooks so that they can be used as teaching aid. One must bear in mind that preparing curricula and prophylactic materials for children, especially with respect to the prevention of different forms of sexual abuse or ensuring physical, mental, emotional, spiritual and sexual safety is not easy. It requires engaging competent people. However, even the best teaching aids will not replace a religion teacher. In practice, religion teachers are not always sufficiently competent to conduct classes on these topics. Frequently, they do not have an opportunity to attend certified training courses. Therefore, it is worth taking this educational need into account and planning an interesting offer of in-service training for religion teachers regarding sexual abuse of children. It requires both cooperation of heads of catechetic departments with relevant entities (e.g. education office, teacher in-service training centre) and services (e.g. police) engaged in prevention and children protection, as well as taking up comprehensive initiatives at the national level (e.g. under the patronage of the Catholic Education Commission of the Polish Episcopal Conference).

\section{BIBLIOGRAPHY}

Act of 26 January 1982 - "Teacher's Charter", consolidated text. Journal of Laws 2006, no. 97 , item 674 as subsequently amended.

Act of 14 December 2016 - Law on Education. Journal of Laws 2017, item 59.

Act of 6 January 1997 - Penal Code. Journal of Laws Journal of Laws 1997, no. 88, item 553. BEISET, Maria, IZDEBSKA, Agnieszka. "Wykorzystywanie seksualne dzieci" ["Sexual abuse of children"]. Dziecko Krzywdzone: teoria, badania, praktyka 2012, 2: 48-66.

BukAŁA, Jerzy, Wątorek, Krzysztof (ed.). Pedofilia jako zagrożenie XXI wieku [Paedophilia as a 21 st century threat]. Kielce: Drukarnia Panzet, 2011.

Catholic Education Commission of the Polish Episcopal Conference. "Klasy I-IV szkoły podstawowej. Katecheza inicjacji w sakramenty pokuty i pojednania oraz Eucharystii. Zaproszeni na ucztę z Jezusem" ["Classes I-IV of the primary school. Religious teaching in initiation of the sacrament of penance and reconciliation as well as the Eucharist. Invited to feast with Jesus"], curriculum number AZ-1-01/18. In: CATHOLIC EDUCATION COMMISSION OF THE POLISH EPISCOPAl CONFERENCE. Program nauczania religii rzymskokatolickiej $w$ przedszkolach $i$ szkotach [Curriculum of Catholic religion teaching at schools and kindergartens], 39-82. Częstochowa: Edycja Świętego Pawła, 2018. 
Catholic Education Commission of the Polish Episcopal Conference. "Klasy V-VIII szkoły podstawowej. Katecheza mistagogiczna, wprowadzająca w historię zbawienia. Bóg kocha i zbawia człowieka" ["Classes V-VIII of the primary school. Mystagogical catechesis, introducing to the history of salvation. God loves and saves man"], curriculum number AZ-2-01/18. In: CATHOLIC EDUCATION COMMISSION OF THE POLISH EPISCOPAL CONFERENCE. Program nauczania religii rzymskokatolickiej $w$ przedszkolach i szkołach [Curriculum of Catholic religion teaching at schools and kindergartens], 85-156. Częstochowa: Edycja Świętego Pawła, 2018.

CZEKALSKI, Ryszard (ed.). Bibliografia katechetyczna 2001-2010 [Catechetical bibliography 2001-2010]. Warszawa: Wydawnictwo UKSW, 2012.

FENIK-GABERLE, Katarzyna, KAŁUCKA, Renata. Ujawnienie przez dziecko wykorzystywania seksualnego pracownikowi oświaty. Scenariusze szkoleń dla pracowników oświaty [A child disclosing sexual abuse to a member of an educational facility personnel. Programme of training for educational personnel]. Warszawa: Ośrodek Rozwoju Edukacji, 2018.

ŁABENDOwICZ, Stanisław. Dydaktyka katechezy [Didactics of catechesis]. Radom: Spatium, 2019.

ŁABENDOwICZ, Stanisław. "Katecheza młodzieży niedostosowanej społecznie" ["Catechesis of socially maladjusted youth"]. Roczniki Teologiczne 65(2018), 11: 89-112.

POlish EPISCOPAl CONFERENCE. Dyrektorium Katechetyczne Kościoła Katolickiego w Polsce [Catechetic Directorium of the Catholic Church in Poland]. Kraków: Wydawnictwo WAM, 2001

Polish EPISCOPAl Conference. Podstawa programowa katechezy Kościoła Katolickiego $w$ Polsce [Core curriculum of Catholic religion catechesis in Poland]. Częstochowa: Edycja Świętego Pawła, 2018.

Polish Scientific Bibliography, https://pbn.nauka.gov.pl/sedno-webapp/ (retrieved: 1.06.2019).

POSPISZYL, Kazimierz. "Pedofilia: kilka poglądów na temat jej genezy" ["Paedophilia: several views on its Genesis"]. Psychologia w Szkole 2004, 2: 87-93.

Regulation of the Minister of National Education of 14 April 1992 on conditions and methods of organising religion teaching in public schools and kindergartens. Journal of Laws 1992, No. 33, item 155 (as subsequently amended).

SAJKOWSKA, Monika. "Problem wykorzystywania seksualnego dzieci" ["Sexual abuse of children"]. Polityka Spoteczna 31(2004), 9: 49-58.

SAJKOWSKA, Monika. "Wykorzystywanie seksualne dzieci: ustalenia terminologiczne, skala zjawiska, oblicza problemu społecznego" ["Sexual abuse of children; terminology, scale, faces of the social issue"]. Dziecko Krzywdzone: teoria, badania, praktyka 2002, 1: 5-28.

SAJKOWSKA, Monika. "Wykorzystywanie seksualne dzieci" ["Sexual abuse of children"], Dziecko. Teoria, badania, praktyka 16(2017), 1:233-234.

TKOCZ, Elżbieta. "Niedostosowanie społeczne młodzieży na tle wychowawczych reperkusji postmodernistycznych przemian społeczno-kulturowych" ["Social maladjustment of young people against the background of educational repercussions of post-modernistic socio-cultural transformations"]. In: Wychowanie $w$ wierze w kontekście przemian wspótczesności [Education in faith in the context of transformations of modernity]. Ed. R. Buchta, S. Dziekoński, 58-66. Katowice: Wydawnictwo Księgarnia św. Jacka, 2011.

ZEllma, Anna, CZUPRYŃSKI, Wojsław, TRYK, Hubert. Rekolekcje szkolne jako forma ewangelizacji dzieci, mtodziezy i dorostych [School retreat as a form of evangelisation of children, youth and adults]. Olsztyn: Wydawnictwo UWM w Olsztynie, 2018.

ZELlMA, Anna. "The mission of a teacher of religion in a contemporary Polish school", Roczniki Teologiczne 65(2018), 11: 5-16. 
Zellma, Anna, Wiszowaty, Edward. O Policje bliższa ludziom. Inspiracje pedagogiczne $w$ stuzbie funkcjonariuszy [Let the police be closer to the people. Pedagogical inspirations in the police service]. Szczytno: Publishing Office WSPoL, 2017.

Zellma, Anna, Wiszowaty, Edward. „Współpraca szkoły z policją w zakresie przeciwdziałania demoralizacji nieletnich" ["Cooperation of schools with the police in preventing demoralisation of youth”]. Studia Koszalińsko-Kotobrzeskie 16(2011), 127-144.

\title{
NAUCZANIE RELIGII JAKO PRZESTRZEŃ PRZECIWDZIAŁANIA WYKORZYSTYWANIU SEKSUALNEMU DZIECI
}

\author{
St res z c z e n e
}

Wykorzystywanie seksualne dzieci jest zjawiskiem, które występuje w różnych środowiskach społecznych. Temat ten obecnie pojawia się coraz częściej nie tylko w badaniach naukowych, ale także w debacie publicznej i w programach profilaktyczno-wychowawczych szkoły. Wciąż jednak brakuje opracowań poświęconych roli nauczania religii w przeciwdziałaniu wykorzystywaniu seksualnemu dzieci. Lekcje religii - z uwagi na ich wychowawczy wymiar i korelację z edukacją szkolną - odgrywają ważną rolę w działalności profilaktycznej. Stanowią odpowiednią przestrzeń do podejmowania inicjatyw w zakresie przeciwdziałania wykorzystywaniu seksualnemu dzieci. W nowych dokumentach programowych nauczania religii w szkole podstawowej wielokrotnie zwraca się uwagę na kwestie związane z bezpiecznym środowiskiem oraz rozpoznawaniem zagrożeń w otoczeniu i odpowiednim reagowaniem. Nauczyciel religii ma nie tylko obowiązek zapewnić uczniom opiekę i bezpieczeństwo, ale także wyposażyć dzieci w wiedzę i umiejętności pozwalające na rozpoznawanie oraz unikanie sytuacji, w których istnieje zagrożenie wykorzystywaniem seksualnym.

Podejmując wyżej zasygnalizowaną problematykę, w niniejszym opracowaniu odwołano się zarówno do prawa oświatowego, jak i do nowych dokumentów programowych nauczania religii. Zwrócono uwagę na cele $\mathrm{i}$ treści oraz na rozwiązania organizacyjne i metodyczne aktywności profilaktycznej w wymienionym zakresie. W tym kontekście wyakcentowano znaczenie współpracy nauczyciela religii z rodzicami, szkołą i odpowiednimi służbami (np. policją). Zaangażowanie rodziców odgrywa bowiem ważną rolę w zapobieganiu wykorzystywaniu seksualnemu dzieci.

Słowa kluczowe: nauczanie religii; nauczyciel religii; wykorzystywanie seksualne; dziecko; profilaktyka; pedagogika. 